\title{
FINANCIAL INCLUSION SUPPORT AND PERFORMANCE OF LIVELIHOOD PROJECT IN RWANDA A CASE OF STREET VENDORS' PROJECT IN GASABO DISTRICT
}

\author{
Sosthene Tuyisenge ${ }^{1 *} \&$ Dr. Paul Munene PhD $^{2}$ \\ ${ }^{*}$ School of Business and Economic; Mount Kenya University Kigali; Rwanda \\ ${ }^{2}$ School of Business and Economic, Mount Kenya University, Kigali, Rwanda
}

\section{*Corresponding Author: -}

Email: tuyisengesosthene@gmail.com

\begin{abstract}
: -
This paper aims at examining the influence of financial inclusion support on performance of livelihood project among street vendors. Data for this study was collected from livelihood projects in Kigali City; Rwanda. The paper tested the hypothesis that there is significant influence of financial inclusion support on performance of livelihood project among street vendors. This study used correlation research design in order to evaluate the influence of project financial inclusion support on performance of livelihood project in Gasabo district; Rwanda. The population of this research were 200 people including street vendors and head of departments as well as managers of financial institutions; while sample size were 134 respondents that was obtained by using Slovin's formula. Questionaires and guided interview were used as data collection instruments where descriptive statistics was used for quantitative data analysis through the software of statistical package for the social sciences(SPSS) version 21;qualitative data were analysed by using thematic method; Karl Pearson product moment correlation coefficient was used to establish relationship between variables while regression analysis was used to check the influence of project financial inclusion support to performance of livelihood project at 16.9 percent of $R$-square. Cronbach's alpha coefficient of 77 percent showed that the instruments were reliable while the validity was established by peer discussion with experts. This study will be significant to head departments, financial inclusion managers, street vendors and MINECOFINE. The findings on the first objective showed that table banking and saving account are considered as capacity building as it was confirmed by 55.5 percent of street vendors that they save money after selling. The findings on the second objective showed that 91.8 percent of the street vendors agreed that they use cashless payment.The findings on the third objective showed that entrepreneurial activities support; monitoring and evaluation influence livelihood project performance, it was also shown that there is significant low degree of positive correlation of 0.402 between capital support and improvement of street vendors' quality and that every increase on us of start-up capital leads to livelihood performance increase somewhere between 7.7 percent and 36.1 percent. It was concluded that effective implementation of project financial inclusion support leads to positive performance of livelihood project. The study recommends that national budget planners and intervening people should provide financial facilities and make effective set up that should enhance performance of livelihood project. The researcher suggests that further research can be done to examine the influence of financial inclusion support on development of livelihood project among street vendors in Rwanda so as to come up with comparative analysis.
\end{abstract}




\section{I.INTRODUCTION}

Globally; The process that ensures the easiness access; availability and usage of financial system by all members of society known as inclusion as supported by (Martinez,2011). Financial inclusion expressed as the process of ensuring that poor people access the basic financial services in the informal sector (Allen et al.,2016). In addition to this; in Indian context financial inclusion support was taken as an increase in number of bank branches in different areas including urban; semi urban and metropolitan regions as it was observed in the period of post liberalization. Yet, a huge number of population is disadvantaged to have access on financial services and products in India as indicated by (Chaia ,2009).In 2014; the launch of PMJDY in India was carried out including people who are in range of 20 and 65 Years which is aiming at making financial facilities accessible as well as affordable to lower and middle -income groups for supporting the performance of livelihood project. Swamy (2012); conducted a study for how inclusive growth can be influenced by financial inclusion in India during 1975-2007 and revealed that financial inclusion aims at inclusive growth and development of performance of livelihood project as well as financial deepening.

In Africa; Mzansi which is considered as a low cost bank account which was launched in South Africa for financially excluded People as South African Banking institutions and Self-help Groups were a head of this launching in 2004 aiming at extending financial services to such group of people. The regulatory frameworks were designed for improving performance of livelihood project including groups with low income like street vendors as well as rural women and children to be able to establish small businesses in order to improve their lives. Robinson, (2001); conducted a study regarding to the impact of financial facilities including micro-savings and micro-credit on reduction in child-labour as well as agricultural production where the researcher revealed that financial facilities have positive impact on child labour reduction as well as increasing agricultural production. Kenya Safaricom's M-Pesa service produced a donor funded experiment to allow the repayment of loans in microfinance using the mobile phone for empowering livelihood projects (Mas \& Morawczynski ,2009).Kenya has the program of empowering women and girls as well through providing financial facilities to Kenya's women and girls 'livelihood projects which was valued as the effective effort between the Kenya Government and CARE International Kenya for improving the lives of Kenya citizens.

Even if Rwanda went through dark period; many reforms was done including political and project financial reforms where it has got incredible growth as is taken as an example of developed country in African continent. In addition to this; From 2011 to 2015 the increase of economy of Rwanda has been shown time to time where it was averaged to $6.9 \%$ as reported by BNR (2016). About performance of livelihood project like in Kenya; Rwanda has the target of empowering those projects through encouraging all Rwandans to work in cooperative as the key for developing the culture of credit and saving. street vendors were given commercial stand in different markets and selling point in order to reduce the confrontation of Rwanda government with street vendors as shown that When poor and vulnerable groups have access to finance; society welfare developed as project financial inclusion support reduces poverty.

Ayana and Martinez (2010); conducted a study about the issue of financial inclusion and revealed that financial inclusion is particularly important for Sub-Saharan Africa and showed that 24 percent of Rwanda citizens use formal financial institutions ;55 percent of East Asia while Eastern Europe has 35 percent of the population with bank accounts as well as have accounts 39 percent in Latin America.

\section{Review of Literature}

\section{A. Financial inclusion support}

Financial inclusion support aims at deepening access to financial services, this term means the availability and usage of bank accounts as means of payments; savings and credit as well as investments or insurance products. Financial inclusion support deepening has taken as the key concern for development policy as stated by (Klaper et al.,2014). The process of providing the required financial services at a fair price regardless to any kind of discrimination to all members of society considered as project financial inclusion (Sarma \& (Pais, 2011). The effect of financial inclusion efforts on performance of livelihood empowerment project for India during 19752007 was examined where the growth enhancing role of bank -based financial intermediation established by Inclusive growth in India has definite advantage and is effectively improved by bank-led project financial inclusion support as revealed in this study (Swamy 2012).

Mobile money transfers as illustrated by M-Pesa in Kenya; has shown that when people are financially included regardless to any kind of discrimination the new projects created as people get capital to start business. In addition to this; East Africa has incredible success of mobile money where this company provides key opportunities to low income people as well as to financial inclusion policymakers that leads them to make policies that favour the excluded customers to access financial facilities easily relying on already existing networks and infrastructures. Financial inclusion support is crucial as it is aiming at ensuring that performance of livelihood project is complete and continued as well as facilitating all sections of people to afford and access the provided formal financial facilities (Bhowmik \&Saha 2013).

\section{B. Performance of livelihood project}

Bruce et al., (2013); conducted a study to see how economic records can be sustained by the national income accounting where the researcher revealed that economic records are not only important to national income accounting but also to economists as it is aiming at seeing how the economy is working as many of policy steps 
depend on the livelihood project performance. Measuring performance of livelihood projects includes measuring an increase of societies wellbeing and giving statistical accuracy of the economic balance and social. Improvement of the performance of livelihood project taken as the constant increase in welfare of a certain individual or company with continual changes in that economic structure; health of people; literacy as well as distribution of income ( Harihanan \& Marktanner, 2012).

When societies change deeply as livelihood performance improves where several measures used to know the level of performance of livelihood project including level of national income; capital allocation and Gross Domestic Products (GDP) compared to others. GDP aims at measuring the extent to which the activities that fall under the boundary of the financial system of a country are produced and estimate the worries as well as difficulties that different areas can meet so that financial development can be affected (OECD, 2006). Street vending is the vending carried out by street vendors who are persons that provides goods to the public for which to sell without having a fixed location from which to sell (Bhowmik \&Saha,2013). Most people engage in such kind of business searching for better life as they failed to get formal employment; that is why they carry out such business as street vending in Zambia because of missing other option (Ndhlovu, 2011). Thus; livelihood project like street vending play crucial role in local economy when work in well-structured place; that is why Rwanda has built markets for such people in order to improve their lives even if they failed to work in those market as they do not have enough capital.

\section{Financial inclusion support and performance of livelihood project}

Financial inclusion support is aiming at helping all people to have equal access to financial facilities through encouraging them having bank accounts; savings and investments as well as credit. Financial deepening has taken as the key concern for development policy as stated by (Klaper et al.,2014). Financial inclusion has positive effects on vulnerable group including street vendors as improves the performance of livelihood projects. Financial deepening has a key concern in policies development while project financial inclusion support is important for the performance of livelihood project by reducing inequality and poverty in any country as cited by World Bank;(2016). Financial inclusion support has the power of improving the access to financial facilities for low income people and micro enterprise to get income earning opportunities and develop their self-sufficiency. The process of contributing and recognising the value of contributions as well as making a fair distribution of their wealth for enhancing the access to financial facilities considered as financial inclusion support. Financial inclusion support plays crucial role in supporting business development and positively affect the performance of economic projects. In addition to this; financial inclusion support influences the performance of livelihood projects since it enables street vendors as vulnerable group to improve their lives by encouraging them to work in cooperative; have saving account; access to credit as well as use of mobile banking. (OECD,2011). Jack and Suri (2014); conducted a study for investigating how risk-sharing can be affected by lowering transaction costs of mobile money using Kenyan panel data and revealed that there is positive influence of lowering transaction costs on risksharing as well as (M-pesa) as a way of mobile money transfers help in reducing income shocks.

Andrianaivo and Kpodar (2011) carried out a study aiming at investigating how economic growth can be affected by the range of Information and Communication Technology indicators (ICT) in African countries during 19882007. The researcher revealed that project financial inclusion support is the key to access financial services and confirm that technology transformation, including mobile money, Mobile banking have a significant contribution to economic growth. According to Ashraf et al., (2010), financial inclusion support leads to better performance of livelihood project by providing savings opportunity as supported savings increase economic growth (Yang, 2012). Poverty reduction and economic growth can be affected by financial inclusion as supported by Bruhn \& Love (2014).

\section{III.Research Methodology}

The study employed correlation research design. The Solvin's formula for sampling and purposive sampling technique were used to select134 respondents from 200 targeted people. Questionnaires and guided interview were used as data collection. SPSS version 21 was used to enter and to analyse the data. Descriptive statistics such as mean, standard deviation and correlation and regression analysis and regression were used to analyze quantitative data while thematic analysis was used to analyze qualitative data.

\section{IV.Research Findings and Discussion}

A.The influence of capacity building on performance of livelihood project among street vendor This sub-section presents descriptive results on capacity building variable. The respondents were required to state their level of agreement or otherwise with the statements relating to capacity building. The scale used was as follows: SD - strongly disagree, D - disagree, N - neutral, A - agree, and SA- strongly agree. The results are shown in Table 1 
Table 1: Perception of street vendors on capacity building

\begin{tabular}{|c|c|c|c|c|c|c|c|c|c|c|c|c|}
\hline \multirow[t]{2}{*}{ Statements } & \multicolumn{2}{|l|}{ SD } & \multicolumn{2}{|l|}{ D } & \multicolumn{2}{|l|}{$\mathrm{N}$} & \multicolumn{2}{|l|}{ A } & \multicolumn{2}{|l|}{ SA } & \multirow[t]{2}{*}{ Mean } & \multirow[t]{2}{*}{ Std } \\
\hline & Freq & $\%$ & Freq & $\%$ & Freq & $\%$ & Freq & $\%$ & Freq & $\%$ & & \\
\hline $\begin{array}{l}\text { The district help } \\
\text { street vendors to } \\
\text { create saving } \\
\text { account }\end{array}$ & 64 & 50.8 & 21 & 16.7 & 14 & 11.1 & 12 & 9.5 & 15 & 11.9 & 2.15 & 1.43 \\
\hline $\begin{array}{lr}\text { Street vendors' } \\
\text { customer } & \text { care } \\
\text { improved } & \end{array}$ & 37 & 29.4 & 42 & 33.3 & 10 & 7.9 & 26 & 20.6 & 11 & 8.7 & 2.46 & 1.33 \\
\hline $\begin{array}{l}\text { Technology } \\
\text { transformation } \\
\text { help street } \\
\text { vendors in time } \\
\text { management }\end{array}$ & 13 & 10.3 & 13 & 10.3 & 45 & 35.7 & 33 & 26.2 & 22 & 17.5 & 3.30 & 1.18 \\
\hline $\begin{array}{lr}\begin{array}{l}\text { Street vendors } \\
\text { improved } \\
\text { quality }\end{array} & \end{array}$ & 9 & 7.1 & 24 & 19 & 29 & 23 & 31 & 24.6 & 33 & 26.2 & 3.43 & 1.26 \\
\hline $\begin{array}{l}\text { Leaders help } \\
\text { street vendors to } \\
\text { know reason why } \\
\text { to save }\end{array}$ & 16 & 12.7 & 27 & 21.4 & 22 & 17.5 & 30 & 23.8 & 31 & 24.6 & 3.26 & 1.14 \\
\hline $\begin{array}{l}\text { I save money after } \\
\text { selling }\end{array}$ & 5 & 4 & 17 & 13.5 & 38 & 30.2 & 32 & 25.4 & 34 & 27 & 3.57 & 1.37 \\
\hline $\begin{array}{l}\text { Street vendors sell } \\
\text { at effective cost }\end{array}$ & 9 & 7.1 & 25 & 19.8 & 22 & 17.5 & 27 & 21.4 & 43 & 34.1 & 3.55 & 1.33 \\
\hline
\end{tabular}

Source: Primary Data (2021). SD: Strongly disagree, D: disagree, N: Neutral, A: Agree and SA: Strongly agree.

The table 1 indicates the perception provided by street vendors related to the influence of capacity building on performance of livelihood project among street vendors; where 55.5 percent of street vendors agreed that they save money after selling at 3.57 of mean ;52.4 percent of street vendors agreed that they sell at effective cost at 3.55 of mean;50.8 percent of street vendors agreed that street vendors improved their quality at 3.43 of mean;43.7 percent of street vendors agreed that technology transformation help them in time management at 3.30 and 29.3 percent of street vendors agreed that street vendors' customer care improved at 2.46 of mean while 21.4 percent of street vendors agreed that the district help street vendors to create saving account at 2.15 of mean .According to the results indicated in the table 4.5 ;it is clear that ;saving money after selling is the most capacity building as shown by the mean of 3.57. However ;head of departments and financial institutional managers found in Gasabo district were given guided interview about the influence of capacity building on performance of livelihood project among street vendors ;indicated that saving after selling ; selling at effective cost ;improving quality ; technology transformation and improvement of street vendors' customer as well as helping street vendors in create saving account by district leads to better performance of street vendors .

They also added that, such capacity building is not effectively done due to insufficient capital.

Basing on the perceptions of different respondents related to the influence of capacity building on performance of livelihood project among street vendors, the researcher made comparative interpretation where it was shown that respondents have the same perception on the influence of capacity building but different magnitude as shown in table1 as well as interview given to head of departments and financial institutional managers. According to Rangarajan Committee (2008); released a report after conducting research about financial inclusion and revealed that financial facilities like saving account; table banking and credit help vulnerable groups of a society, such as low-income groups and the weaker sections, get access to the financial system and be able to get timely and adequate credit at affordable cost.

\section{B. Regression analysis}

The R square of capacity building and performance of livelihood project is depicted in table 2

Table 2: The R square of capacity building and performance of livelihood project

\begin{tabular}{|c|c|c|c|c|c|c|c|c|c|}
\hline \multirow[b]{2}{*}{ Model } & \multirow[b]{2}{*}{$\mathrm{R}$} & \multirow[b]{2}{*}{ R Square } & \multirow[b]{2}{*}{$\begin{array}{l}\text { Adjusted } \\
\text { R Square }\end{array}$} & \multirow{2}{*}{$\begin{array}{l}\text { Std. Error } \\
\text { of the } \\
\text { Estimate }\end{array}$} & \multicolumn{5}{|c|}{ Change Statistics } \\
\hline & & & & & $\begin{array}{l}\text { R Square } \\
\text { Change }\end{array}$ & $\begin{array}{l}\mathrm{F} \\
\text { Change }\end{array}$ & dfl & $\mathrm{df} 2$ & $\begin{array}{l}\text { Sig. } F \\
\text { Change }\end{array}$ \\
\hline 1 & $.411^{\mathrm{a}}$ & .169 & .149 & 1.22720 & .169 & 8.273 & 3 & 122 & .000 \\
\hline
\end{tabular}

Source: Primary (2021),a. Predictors: (Constant),capacity building 
The table 4.5 indicates the influence of capacity building on performance of livelihood project among street vendors. Where the findings presented that there is a low degree of correlation ( $\mathrm{r}$ ) of 0.441 and $\mathrm{R}$ square of 0 . 169.It means that capacity building has low influence on performance of livelihood project at 16.9 percent.

\section{Digital transformation and performance of livelihood project among street vendors}

This sub-section presents descriptive results on digital transformation variable. The respondents were required to state their level of agreement or otherwise with the statements relating to capacity building. The scale used was as follows: SD - strongly disagree, D - disagree, N - neutral, A - agree, and SA- strongly agree. The results are shown in Table 4.3

Table 4. 3: Perception of street vendors on digital transformation

\begin{tabular}{|c|c|c|c|c|c|c|c|c|c|c|c|c|}
\hline \multirow[t]{2}{*}{ Statements } & \multicolumn{2}{|l|}{ SD } & \multicolumn{2}{|l|}{ D } & \multicolumn{2}{|l|}{$\mathrm{N}$} & \multicolumn{2}{|l|}{ A } & \multicolumn{2}{|l|}{ SA } & \multirow[t]{2}{*}{ Mean } & \multirow[t]{2}{*}{ Std } \\
\hline & Freq & $\%$ & Freq & $\%$ & Freq & $\%$ & Freq & $\%$ & Freq & $\%$ & & \\
\hline $\begin{array}{l}\text { Mobile } \\
\text { banking } \\
\text { improves the } \\
\text { level of street } \\
\text { vendors' } \\
\text { economy }\end{array}$ & 12 & 9.5 & 14 & 11.1 & 19 & 15.1 & 38 & 30.2 & 43 & 34.1 & 3.68 & 1.30 \\
\hline $\begin{array}{l}\text { Customers } \\
\text { satisfied when } \\
\text { street vendors } \\
\text { use mobile } \\
\text { money }\end{array}$ & 3 & 2.4 & 5 & 4 & 17 & 13.5 & 36 & 28.6 & 65 & 51.6 & 4.23 & 0.98 \\
\hline $\begin{array}{l}\text { Use of } \\
\text { cashless } \\
\text { payment help } \\
\text { street vendors } \\
\text { to manage } \\
\text { time at high } \\
\text { level }\end{array}$ & 3 & 2.4 & 9 & 7.1 & 11 & 8.7 & 37 & 29.4 & 66 & 52.4 & 4.22 & 1.03 \\
\hline $\begin{array}{l}\text { Street } \\
\text { vendors' ATM } \\
\text { usage reduce } \\
\text { time westage }\end{array}$ & 13 & 10.3 & 23 & 18.3 & 21 & 16.7 & 26 & 20.6 & 43 & 34.1 & 3.50 & 1.38 \\
\hline $\begin{array}{l}\text { Quality and } \\
\text { sustainability } \\
\text { can be } \\
\text { influenced by } \\
\text { money } \\
\text { transfer }\end{array}$ & 2 & 1.6 & 5 & 4 & 11 & 8.7 & 34 & 27 & 74 & 56.7 & 4.37 & 0.91 \\
\hline
\end{tabular}

Source: Primary data (2021). SD: Strongly disagree, D: disagree, N: Neutral, A: Agree and SA: Strongly agree.

The table 4.3 indicates the perception provided by street vendors related to the influence of digital transformation on performance of livelihood project among street vendors; where 91.8 percent of street vendors agreed that Use of cashless payment help street vendors to manage time at high level at 4.22 of mean ;83.7 percent of street vendors agreed that their Quality and sustainability can be influenced by money transfer at 4.37of mean;80.2 percent of street vendors agreed that Customers satisfied when street vendors use mobile money at 4.23 of mean;64.3 percent of street vendors agreed Mobile banking improves the level of street vendors' economy at 3.68 while 54.7 percent of street vendors agreed that Street vendors' ATM usage reduce time wastage at 3.50 of mean

.According to the results indicated in the table 4.10;it is clear that ; Use of cashless payment help street vendors to manage time at high level is the most digital transformation as shown by the mean of 4.22.However ; head of departments and financial institutional managers found in Gasabo district were given guided interview about the influence of digital transformation on performance of livelihood project among street vendors ;indicated that cashless payment Money transfer; mobile banking and street vendors' ATM usage as indicators of digital transformation can influence performance of livelihood project.

Basing on the perceptions of different respondents related to the influence of digital transformation on performance of livelihood project among street vendors, the researcher made comparative interpretation where it was shown that respondents have the same perception on the influence of digital transformation but different magnitude as shown in table 4.9 as well as interview given to head of departments and financial institutional managers. 


\section{The R square of digital transformation and performance of livelihood project}

\begin{tabular}{|c|c|c|c|c|c|c|c|c|c|}
\hline \multirow[b]{2}{*}{ Model } & \multirow[b]{2}{*}{$\mathrm{R}$} & \multirow[b]{2}{*}{$\begin{array}{l}\mathrm{R} \\
\text { Square }\end{array}$} & \multirow[b]{2}{*}{$\begin{array}{l}\text { Adjusted } \\
\text { R Square }\end{array}$} & \multirow{2}{*}{$\begin{array}{l}\text { Std. } \\
\text { Error of } \\
\text { the } \\
\text { Estimate }\end{array}$} & \multicolumn{5}{|c|}{ Change Statistics } \\
\hline & & & & & $\begin{array}{l}\mathrm{R} \\
\text { Square } \\
\text { Change }\end{array}$ & $\begin{array}{l}\mathrm{F} \\
\text { Change }\end{array}$ & df1 & df2 & $\begin{array}{l}\text { Sig. F } \\
\text { Change }\end{array}$ \\
\hline 1 & $.339^{\mathrm{a}}$ & .115 & .094 & .94186 & .115 & 5.298 & 3 & 122 & .002 \\
\hline
\end{tabular}

Source: Field data (2021),a. Predictors: (Constant),Digital transformation.

The table 4.4, indicates the influence of digital transformation on performance of livelihood project among street vendors. Where the findings presented that there is a low degree of correlation (r) of 0.339 and $\mathrm{R}$ square of 0 . 115.It means that digital transformation has low influence on performance of livelihood project at 11.5 percent

E. Entrepreneurial activities support and performance of livelihood project among street vendors This sub-section presents descriptive results on Entrepreneurial activities support variable. The respondents were required to state their level of agreement or otherwise with the statements relating to capacity building. The scale used was as follows: SA - strongly disagree, D - disagree, N - neutral, A - agree, and SA - strongly agree. The results are shown in Table 5

Table 5: Perception of street vendors on entrepreneurial activities support

\begin{tabular}{|c|c|c|c|c|c|c|c|c|c|c|c|c|}
\hline \multirow{2}{*}{ Statements } & \multicolumn{2}{|l|}{ SD } & \multicolumn{2}{|l|}{$\mathrm{D}$} & \multicolumn{2}{|l|}{$\mathrm{N}$} & \multicolumn{2}{|l|}{ A } & \multicolumn{2}{|l|}{ SA } & \multirow[t]{2}{*}{ Mean } & \multirow[t]{2}{*}{ Std } \\
\hline & Freq & $\%$ & Freq & $\%$ & Freq & $\%$ & Freq & $\%$ & Freq & $\%$ & & \\
\hline $\begin{array}{l}\text { Most of street } \\
\text { vendors have } \\
\text { bank account }\end{array}$ & 17 & 18.5 & 18 & 14.3 & 31 & 24.6 & 35 & 27.8 & 25 & 19.8 & 3.26 & 1.30 \\
\hline $\begin{array}{l}\text { Street vendors } \\
\text { improve their } \\
\text { project quality }\end{array}$ & 2 & 6.3 & 16 & 12.7 & 28 & 22.2 & 41 & 32.5 & 33 & 26.2 & 3.59 & 1.18 \\
\hline $\begin{array}{l}\text { Stakeholders } \\
\text { monitor } \\
\text { influence } \\
\text { street vendors } \\
\text { to sell at } \\
\text { affordable } \\
\text { cost }\end{array}$ & 5 & 4 & 23 & 18.3 & 22 & 17.5 & 32 & 25.4 & 44 & 24.9 & 3.69 & 1.23 \\
\hline $\begin{array}{l}\text { Street vendors } \\
\text { manage their } \\
\text { time well }\end{array}$ & 4 & 3.2 & 6 & 4.8 & 18 & 14.3 & 35 & 27.8 & 63 & 50 & 4.16 & 1.04 \\
\hline $\begin{array}{l}\text { Ownership } \\
\text { account affect } \\
\text { street vendors' } \\
\text { project quality } \\
\text { in this district }\end{array}$ & 9 & 7.1 & 11 & 8.7 & 12 & 9.5 & 31 & 24.6 & 63 & 50 & 4.01 & 1.26 \\
\hline $\begin{array}{l}\text { Start-up } \\
\text { capital support } \\
\text { influence } \\
\text { project quality } \\
\text { and } \\
\text { sustainability }\end{array}$ & 7 & 5.6 & 5 & 4 & 12 & 9.5 & 27 & 21.4 & 75 & 59.5 & 4.25 & 1.12 \\
\hline
\end{tabular}

Source: Primary data (2021). SD: Strongly disagree, D: disagree, N: Neutral, A: Agree and SA: Strongly agree.

The table 5 indicates the perception provided by street vendors related to the influence of entrepreneurial activities support on performance of livelihood project among street vendors; where 80.9 percent of street vendors agreed that Start-up capital support influence project quality and sustainability at 4.25 of mean ;77.8 percent of street vendors agreed that Street vendors manage their time well at 4.16 of mean;74.6 percent of street vendors agreed that Ownership account affect street vendors' project quality at 4.01 of mean;58.7 percent of street vendors agreed that Street vendors improve their project quality at 3.39 of meanwhile 50.3 percent of street vendors agreed that Stakeholders monitor influence street vendors to sell at affordable cost at 3.69 of mean as well as 47.6 percent of street vendors agreed that Most of street vendors have bank account at 3.26 of mean .According to the results indicated in the table 4.5;it is clear that ; Start-up capital support influence project quality and sustainability significantly as shown by mean of 4.25 . However ; head of departments and financial institutional managers found in Gasabo district were given guided interview about the influence of entrepreneurial activities support; monitoring and evaluation on performance of livelihood project among street vendors ;indicated that entrepreneurial activities support; monitoring and evaluation; Start-up capital support and ownership account have significant influence on performance of livelihood project.Basing on the perceptions of different respondents related to the influence of entrepreneurial activities; monitoring and evaluation on performance of livelihood project among street vendors, the researcher made comparative interpretation where it was shown that respondents have the same perception on the influence of entrepreneurial activities ;monitoring and evaluation but different magnitude as shown in table 4.5 as well as interview given to head of departments and financial institutional managers. 


\section{F. The R square of entrepreneurial activities support and performance of livelihood project}

\begin{tabular}{|c|c|c|c|c|c|c|c|c|c|}
\hline \multirow[b]{2}{*}{ Model } & \multirow[b]{2}{*}{$\mathrm{R}$} & \multirow[b]{2}{*}{$\begin{array}{l}\mathrm{R} \\
\text { Square }\end{array}$} & \multirow[b]{2}{*}{$\begin{array}{l}\text { Adjusted } \\
\text { R Square }\end{array}$} & \multirow{2}{*}{$\begin{array}{l}\text { Std. Error } \\
\text { of the } \\
\text { Estimate }\end{array}$} & \multicolumn{5}{|c|}{ Change Statistics } \\
\hline & & & & & $\begin{array}{l}\text { R Square } \\
\text { Change }\end{array}$ & $\begin{array}{l}\mathrm{F} \\
\text { Change }\end{array}$ & df1 & df2 & $\begin{array}{l}\text { Sig. F } \\
\text { Change }\end{array}$ \\
\hline 1 & $.390^{\mathrm{a}}$ & .152 & .131 & .97750 & .152 & 7.301 & 3 & 122 & .000 \\
\hline
\end{tabular}

Source: Field data (2021), a. Predictors: (Constant), Entrepreneurial activities support.

The table 6, indicates the influence of entrepreneurial activities on performance of livelihood project among street vendors. Where the findings presented that there is a low degree of correlation (r) of 0.390 and R square of 0 . 152.It means that entrepreneurial activities; monitoring and evaluation has low positive influence on performance of livelihood project at 15.2 percent.

G. Correlation between project financial inclusion support and performance of livelihood project among street vendors in Gasabo district in Rwanda

The findings of correlation between project financial inclusion support and performance of livelihood project among street vendors are presented in table 7

Table 7: Correlation between project financial inclusion support and performance of livelihood project among street vendors in Gasabo district in Rwanda.

\begin{tabular}{|c|c|c|c|c|c|}
\hline & & $\begin{array}{l}\text { performance } \\
\text { of livelihood } \\
\text { project }\end{array}$ & $\begin{array}{l}\text { capacity } \\
\text { building }\end{array}$ & $\begin{array}{l}\text { digital } \\
\text { transformation }\end{array}$ & $\begin{array}{l}\text { entrepreneurial } \\
\text { activities support }\end{array}$ \\
\hline \multirow[t]{3}{*}{$\begin{array}{l}\text { performance of } \\
\text { livelihood project }\end{array}$} & $\begin{array}{l}\text { Pearson } \\
\text { Correlation }\end{array}$ & 1 & $.580^{* *}$ & $.325^{* *}$ & $.402^{* *}$ \\
\hline & Sig. (2-tailed) & 0.00 & 0.00 & 0.00 & 0.00 \\
\hline & $\mathrm{N}$ & 126 & 126 & 126 & 126 \\
\hline \multirow[t]{3}{*}{ capacity building } & $\begin{array}{l}\text { Pearson } \\
\text { Correlation }\end{array}$ & $.580^{* *}$ & 1 & 0.339 & 0.390 \\
\hline & Sig. (2-tailed) & 0.00 & 0.000 & 0.00 & 0.00 \\
\hline & $\mathrm{N}$ & 126 & 126 & 126 & 126 \\
\hline \multirow[t]{3}{*}{$\begin{array}{l}\text { digital } \\
\text { transformation }\end{array}$} & $\begin{array}{l}\text { Pearson } \\
\text { Correlation }\end{array}$ & $.325^{* *}$ & $0.339^{*}$ & 1 & $0.390^{\circ}$ \\
\hline & Sig. (2-tailed) & 0.00 & 0.000 & 0.003 & 0.001 \\
\hline & $\mathrm{N}$ & & 126 & 126 & 126 \\
\hline \multirow[t]{3}{*}{$\begin{array}{l}\text { entrepreneurial } \\
\text { activities support }\end{array}$} & $\begin{array}{l}\text { Pearson } \\
\text { Correlation }\end{array}$ & $.402^{* *}$ & $0.411^{*}$ & $0.390^{\circ}$ & 1 \\
\hline & Sig. (2-tailed) & 0.00 & 0.00 & 0.00 & 0.00 \\
\hline & $\mathrm{N}$ & 126 & 126 & 126 & 126 \\
\hline
\end{tabular}

**. Correlation is significant at the 0.01 level (2-tailed).

The study investigated the relationship between digital transformation and performance of livelihood project basing on independent variable. The results investigated that there is a significance high degree of positive correlation between digital transformation and performance where Pearson coefficient of correlation states the correlation $(r)$ of 0.325 with the $p$-value $=0.000<0.01$. This means that digital transformation as project financial inclusion support performance provides enough evidence that promote performance of livelihood project as indicated by customers' satisfaction. As stated in interview, it was shown that the more street vendors are financially included the more their performance improved. The study investigated the relationship between project entrepreneurial activities support and performance of livelihood project basing on independent variable. The investigated that there is a significance high degree of positive correlation between entrepreneurial activities support and performance of livelihood project Indicated by improvement of street vendors' quality where Pearson coefficient of correlation states the correlation $(r)$ of 0.402 with the $p$-value $=0.000<0.01$. This means that entrepreneurial activities support as start-up capital support provides enough evidence that promote performance of livelihood project as improvement of street vendors' quality. As stated in interview, it was shown that the more street vendors are financially included the more their performance improvedThe study investigated the relationship between Capacity building and performance of livelihood project the results in the table 4.8, revealed that there is a significance high degree of positive correlation between Capacity building and performance of livelihood project where Pearson coefficient of correlation states the correlation ( $r$ ) of 0.580 with the pvalue $=0.000<0.01$. This means that project financial inclusion support provides enough evidence that promote performance of livelihood project. As stated in interview, it was shown that the more street vendors are financially included the more their performance improved. 


\section{Conclusion and Recommendation}

Throughout the study it was concluded that there is significant influence of financial inclusion support on performance of livelihood project among street vendors in Gasabo district in Rwanda as indicated by 91.8 percent of street vendors who agreed that use of cashless payment influence project quality and sustainability at 4.23 of mean. It was also shown that financial inclusion support is positively correlated to performance of livelihood project as indicated by ( $\mathrm{r}$ ) of 0.339 . Basing on the findings of this study and the presented conclusion, the following recommendations were addressed to ministry of microfinance, national budget planners and financial institutional managers.Ministry of microfinance, should provide financial facilities to street vendors so that they can stop selling in street and have fixed selling point;National budget planners should make effective set up that should enhance performance of livelihood project so as to make up effective implementation of project financial inclusion support among street vendors in Rwanda and Financial institutional managers should follow up the implementation of project financial inclusion support daily so that performance of livelihood project among street vendors can be improved.

\section{VI.Acknowledgment}

Humbly and honestly, I would like to thank our father almighty God for his fruitful results of this plan, guidance ,protection and blessing towards me .I acknowledge the moral and financial support of my mother Nyiratuza Daphrose, special thanks to my supervisor, Dr Munene Paul because of his guidance and cancelling during this work .My appreciation to all my brothers, sisters and relatives for their incredible patience and support, much special thanks go to all my friends and classmates MBA students September 2019 especially Izabayo Fabien, Cisca and Asifiwe for their supportive and their strong friendship in my studies ,my sincere gratitude is extended to the lecturers of Mount Kenya University, especially those who taught me at Master's level and to all staff members.

\section{References}

[1].Andrianaivo, M., \& Kpodar, K. (2011). ICT, Financial Inclusion and Growth: Evidence from African Countries.

[2].IMF WP/11/73.

[3].Swamy, V. (2012). Bank-Based Financial Intermediation for Financial Inclusion and Inclusive Growth. Martinez M.V.(2011) The Political Economy of Increased Financial Access. A Thesis Submitted in Partial

[4].Fulfilment of The Requirement for The Degree of Master of Public Policy to the Faculty of the Graduate School of Arts and Sciences of Georgetown University.

[5].Sarma, M. and J. Pais (2011) 'Financial Inclusion and Development', Journal of International Development 23(5): 613-628.

[6].Sarma, S. (2016) 'Meaningful Financial Inclusion', Journal of Rural Development 34(1): 115-120.

[7].Allen, F, Demirguc-Kunt, A, Klapper, L and Martinez Peria, M.S. (2016), The Foundations of Financial Inclusion:

[8].Understanding Ownership and Use of Formal Accounts, Journal of Financial Intermediation.

[9].Karpowicz, I. (2014). Financial Inclusion, Growth and Inequality: A Model Application to Colombia. IMF WP/14/166.

[10]. Hariharan, G., \& Marktanner, M. (2012). The Growth Potential from Financial Inclusion. Draft submitted for Atlanta Fed/GSU International Development Economics.

[11]. Jack, W., \& Suri, T. (2014). Risk Sharing and Transactions Costs: Evidence from Kenya's Mobile Money Revolution. American Economic Review, 104(1), 183-223.

[12]. Ashraf, N., Karlan, D., \& Yin, W. (2010). Female Empowerment: Impact of a Commitment Savings Product in the Philippines. World Development, 38(3), 333-344. Crossref

[13]. Levine, R., Loayza, N., \& Beck, T. (2000). Financial Inclusion and Growth: Causality and Causes. Journal of Monetary Economics, 46, 31-77. 